\title{
0 Cilindro e o Cone
}

\author{
Paulo Vieira N eto \\ Universidade Federal do Paraná
}

\begin{abstract}
resumo Examinamos a argumentação de Cícero contra 0 estoicismo no De Fato tentando reconstruir a melhor argumentação de Crisipo para a posição de uma filosofia que concilie a postulação do destino com a da liberdade humana. Fazemos isso, contudo tendo em vista a maneira como esse programa estóico é lembrado por Leibniz na Teodicéia. A estratégia para tanto consiste em examinar primeiro a maneira como Crisipo e Cícero poderiam traduzir o problema da relação do destino em termos causais, sugerindo uma diferença possível entre a solução que seria legitimamente a de Crisipo e a de Cícero. Depois, mas em função dessa primeira análise, procuramos entender como Crisipo poderia resolver o problema a partir da postulação autonomia do agente na deliberação, pressuposta a natureza do agente - e pressupostos alguns temas centrais da física e da lógica estóicas como a noção de corporais e incorporais. Aqui aparece o exemplo do cilindro e do cone, como atribuído a Crisipo por Cícero, exemplo cuja interpretação ocupará o restante do artigo.
\end{abstract}

palavras chave Crisipo - Cicero - destino - liberdade - autonomia

\section{$\S 1$}

Leibniz, no Prefácio àTeodicéia, examina as sombras que projeta "A idéia mal entendida da necessidade, quando se aplica à prática" 1 . São duas: 0 fatum mahumetanum - a completa desconsideração da autonomia do agente em nome do destino - e o fatum stoicum figura que "não é tão sombria quanto a fazem parecer" porque tende a "conferir tranqüilidade a respeito dos acontecimentos pela consideração da necessidade que torna

R ecebido em junho de 2005. A ceito em setembro de 2005.

doispontos, Curitiba, São C arlos, vol. 2, n. 1, p.135-170, outubro, 2005 
nossas preocupações e angústias desnecessárias" 2. A simpatia leibniziana pela segunda opinião sobre o destino se estende a ponto de observar que, nesse caso ao menos, os estóicos "não se afastaram inteiramente da doutrina de N osso Senhor". N ão, na medida em que tal doutrina nos torna pacientes diante do destino. $M$ as justamente aqui cabe uma importante ressalva. Para além da doutrina estóica:

“... N osso Senhor inspira os pensamentos mais sublimes, nos mostra mesmo o meio de ter um contentamento quando nos assegura que D eus é perfeitamente bom e sábio,tomando conta de tudo e a tal ponto que não negligenciou sequer um fio de cabelo em nossas cabeças. A ssim, nossa confiança nele deve ser inteira, de sorte que veremos, se formos capazes de compreender,que não teremos meio de esperar algo melhor do que Ele o faz (em absoluto e para nós)" 3

O ra, segundo Leibniz, a necessidade cristã - ou a necessidade bem compreendida, o que equivale - é sublime porque ultrapassa a paciência estóica na direção do contentamento ele mesmo. Diferença considerável no resultado, mas não tão surpreendente em algumas premissas importantes. 0 estoicismo, para aTeodicéia, certamente, não fornece a resposta completa e sublime ao dilema entre liberdade e destino, disponível apenas a partir da revelação cristã, todavia já permite antever a manobra raciona lizante que a postulação de um destino que não contradiz a liberdade dos agentes individuais permite levar a cabo.

Por outro lado, a exceção estóica, como um antepassado da tese leibniziana, ganha um relevo tão mais interessante quanto se encontra mesmo no estoicismo antigo, ou no estoicismo paradoxal como o de Crisipo, um pouco da luz que só irá brilhar completamente após a revelação. 0 que poderia parecer mais relevante, entretanto, é que, aceito este lampejo de compreensão da filosofia pagã a respeito da relação entre destino e liberdade, restaria, mesmo após a revelação a necessidade racional do compromisso de confiança em um D eus onipotente, ou em sua Providência, entendidos em uma chave cristã - e, de fato, são apontados por Leibniz dois dos principais motivos para isso: as dificuldades em 1) garantir a preservação da liberdade humana uma vez presumida a ação de um Deus criador ordenando o mundo, e 2) garantir a racionalidade perfeita da ação divina. É principalmente em relação ao primeiro ponto 
que os estóicos lançam al guma luz, sobretudo porque os testemunhos a respeito da maneira como o estoicismo responde a isso vinculam o problema à investigação a respeito da origem do mal moral, mesmo considerando o caráter pagão da resposta e, portanto, seu descompromisso com a idéia de criação. Portanto, algo da incompreensão a respeito do problema da liberdade humana se reflete no caráter aparentemente paradoxal dos argumentos estóicos a este respeito, uma dificuldade cujo esclarecimento permite a Leibniz conduzir seu leitor do fatum stoicum ao fatum christianum por uma linha contínua.

A este respeito - e a respeito da incompreensão que parece cobrir todas essas questões mesmo para aqueles que já partem da fé cristã - é especialmente interessante 0 exemplo de Bayle, em particular de Bayle leitor do D e F ato ciceroniano. Toda dificuldade da leitura de Bayle, acompanhado por C ícero como veremos adiante, consiste em não conseguir escapar à seguinte disjunção: ou o destino ou a liberdade humana.Todavia, C ícero, no D e F ato, enfrenta nada menos que um argumento de Crisipo cuja intenção é certamente a de impedir a colocação do problema na forma dessa disjunção. Leibniz, a quarta variável nessa sucessão de autores, recupera justamente 0 argumento de Crisipo, sobretudo no momento em que o C risipo ciceroniano propõe um símile: assim como um cone desliza sobre um plano de uma forma diversa daquela que o faria um cilindro, cada agente, por si mesmo, age de acordo com sua natureza em cada acontecimento que 0 destino Ihe impõe $e^{4}$. Leibniz, por sua vez, não deixa de atestar a pertinência dessa imagem de Crisipo, ao compará-la com a que ele mesmo propusera naTeodicéia:

"Esta comparação de C risipo não difere muito da nossa, que tomava um barco carregado levado pela corrente de um rio, mas levado mais lentamente à medida em que a carga era maior". Theodicée, op. cit. (LEIBN IZ 1996a) $)^{5}$

\section{$\S 2$}

Q uatro autores, refratados uns pela apropriação dos outros, estão envolvidos nas passagens em que Leibniz retoma C risipo naTeodicéia. É preciso, no entanto levar em conta a forma pela qual reencontramos os perso- 


\section{8}

nagens, sua imagens e situações nessa trama. C risipo, cujas obras não chegaram a nós, é por isso mesmo a imagem com menor definição, para Leibniz, para Bayle e para nós: sua aparição se esconde através do testemunho de Cícero no D e F ato.Todavia, o tempo não poupa o testemunho ele próprio. Cícero aparece como autor em uma obra de próprio punho, obra que, contudo, chega a nós incompleta. Bayle aparece diretamente nas citações da Teodicéia e no Dicionário, obra na qual investiga os textos ciceronianos, mas também nas referências indiretas, cuidadosas e sobretudo críticas de Leibniz. Leibniz ele mesmo - cuja presença se firma pelo texto estabelecido daTeodicéia - não deixa de se revelar também nos reflexos de $C$ risipo, com quem concorda, ainda que filtrado pelas apresentações críticas de Bayle e Cícero. Enfim, os quatro autores aparecem entremesclados pelo problema de pensar a liberdade humana diante do destino ainda que a compreensão recíproca seja difícil em al guns momentos, truncada sob vários aspectos e talvez impossível em algumas instâncias.

Bayle e Leibniz se unem como conhecedores da revelação cristã, Cícero e C risipo se unem em seu paganismo, mas Cícero e Bayle também se unem em sua defesa da liberdade humana diante do destino e Leibniz e C risipo concordam em sua recusa da disjunção entre a postulação da liberdade humana e a aceitação do destino. D e Cícero a Bayle há um salto em direção ao cristianismo - que Leibniz considerava um salto ao sublime - de Crisipo a Leibniz também. M as será principalmente nas raz ões, e em especial nas razões apresentadas pelo $D$ e $F$ ato e observadas por Leibniz e Bayle que poderemos construir melhor esse quadrilátero segundo as proporções que ele implica. $\mathrm{N}$ um primeiro momento poderíamos dizer, salva a diferença implicada pela fé, que Bayle está para Cícero como Leibniz está para C risipo, e que a imagem de C risipo, o símile do cone e do cilindro, pode servir de paradigma para entendermos as dificuldades e as estratégias implícitas no argumento Leibniziano a favor da convivência da providência e da liberdade humana, como ele aparece naTeodicéia.

Antes de um passo tão arriscado, contudo, seja feito um ajuste preparatório. $\mathrm{N}$ ão se trata aqui de filiar Leibniz ao estoicismo, pela sua adesão a teses estóicas. 0 historiador da filosofia, nesse caso como em muitos outros, tem que se perguntar previamente pelos direitos a uma tal operação redutiva. 0 estoicismo, em particular parece incluir seu caráter sistemático na constituição mesma de suas doutrinaş. A ssim, seria no míni- 
mo inadequado supor que a adoção de teses isoladas pudesse significar uma filiação - cujo preço, no caso do estoicismo envolve a aceitação do todo, mais que a das partes. Seria igualmente inadequado pensar em um leibnizianismo estóico ou num estoicismo lebniziano por razões que a história do pensamento encontra explícitas nas obras mesmas de cada uma dessas filosofias - entre elas o papel que a revelação e os mistérios da fé cristã impõe à filosofia leibniziana. Isso não exclui, em contrapartida uma semelhança de família que se exprime em uma homologia argumentativa que não termina em filiação - basta, para entender isso, um conceito de parentesco mais alargado.

Assim, uma análise do argumento contido no D eF ato, particularmente nos argumentos que giram em torno do símile do cone e do cilindro, pode ser esclarecedora do argumento leibniziano de uma forma muito especial. Podemos repropor o problema nos seguintes termos traçar uma reta para lela a uma reta dada (a desavença entre C ícero e C risipo) que passa por um ponto dado (a pertinência do exemplo do cilindro e do cone) para adivinharmos o precurso da segunda paralela (a posição do problema da relação entre a liberdade humana e a Providência em Leibniz) - salva a possível solução não euclidiana, uma vez que, adiante, examinaremos o D e F ato, apenas, como uma superfície plana na qual tudo isso acontece.

\section{$\S 3$}

N o D e F ato, Cícero cataloga três posições a respeito do preciso limite que se impõe entre, de um lado, a autonomia da ação voluntária e deliberada e, de outro, o destino do mundo. A primeira opinião concede ao destino governo sobre a vontade (reunindo, nos termos do catálogo ciceroniano, D emócrito, $\mathrm{H}$ eráclito, Empédocles e, surpreendentemente, A ristóteles); a segunda, cujos simpatizantes não são elencados por Cícero, nega em absoluto a ação do destino sobre a ação autônoma7. A terceira via, por fim, procura manter a autonomia dos agentes livres sem enfraquecer 0 peso do destino, constituindo-se, particularmente, na maneira estóica de responder ao problema.

Tal esquema divisório parece partir de um critério simples e direto: assim, Cícero organizaria as filosofias pelas respostas que elas oferecem ao 
mesmo problema - o que de fato se propõe como uma aparência forte. Com efeito, se a classificação de Cícero pudesse ser aceita apenas como uma disjunção em três possibilidades, tudo se passaria como se as opiniões divergissem no mesmo plano no qual se distribuem as orientações divergentes das filosofias históricas. Essa aparência, no entanto, não resiste a um exame mais detido. É que podemos divisar uma sutileza ciceroniana: imiscuído no primeiro critério de articulação das facções filosóficas (o de afirmar ou negar a autonomia do agente), insinua-se um segundo, que aparta os estóicos de todos os outros filósofos.

Para C ícero, os estóicos destoam dos outros filósofos a tal ponto que põem em cheque a capacidade de demarcar as fronteiras que dividem a geografia política das escolas antigas em territórios bem distribuídos. A rigor, Cícero aceita a existência de dois continentes, o que, de um lado, abriga os que aceitam a possibilidade de ação deliberada, de outro, 0 que acolhe os que não aceitam. Como Cícero vincula o reconhecimento da autonomia do agente à não aceitação do destino, poderíamos reformular a partilha de escolas nos seguintes termos: os que não acatam a existência do destino e os que por acatá-la são forçados a recusar a possibilidade de uma ação deliberada. M as, para Cícero há somente estes dois territórios. Aqui a originalidade desconcertante dos estóicos. $\mathrm{N}$ o caso estóico, sobretudo, divisa-se a pretensão à existência de um terceiro território, algo como uma insula mirabilis para além do horizonte conhecido - pretensão que o texto ciceroniano manterá sob suspeita até 0 final de sua investigação.

A saber, tanto os que negam quanto os que afirmam a autonomia humana diante do destino concedem a contradição entre as duas coisas. O s estóicos, solitários no catálogo de C ícero, negam justamente esta contraditoriedade, formando com isso um partido diferente, e em um sentido especial. A ssim, a catalogação histórica das opiniões filosóficas, como feita pelo $D$ e $F$ ato, reconhece em primeiro e segundo lugar a antinomia perfeita que concerne à aceitação definitiva do governo do destino ou a da ação autônoma, mas concede estranhamente como terceira possibilidade a dissolução dessa mesma antinomia - e, certamente, se for assim, a posição dos estóicos destoa das duas anteriores, mas não se mantém mais no mesmo plano que elas, porque questiona algo que as duas anteriores tomavam como pressuposto de seu dissenso. 
0 que chama a atenção, no entanto, é a posteridade dessa posição dissonante, cuja paternidade Cícero atribui aos estóicos, isto é, o sucesso que teve a intenção de resolver a contradição entre destino e autonomia sem alguma revogação reáproca, e os mantendo em relação direta. É claro que um certo caráter paradoxal, cuja ironia ciceroniana não deixa de ressaltar, limita o sucesso da opinião estóica porque, no mínimo, diminui muito seu poder persuasivo. A história mesma da questão mostra isso. Se já atentamos à distribuição desigual de escolas filosóficas dentro dos limites de cada uma das opiniões concorrentes, percebemos também o caráter de exceção da tentativa estóica.

Sejam consideradas as alternativas enumeradas pelo autor. $R$ epresentantes da primeira posição (os deterministas) parecem ser razoavelmente incomuns na história da filosofia, embora C ícero enumere vários e situe dentre eles, de maneira equivocada, o próprio A ristóteles. 0 s da segunda (os que defendem a autonomia humana) deveriam ser muito mais freqüentes, mas não são enumerados por Cícero - e talvez não precisassem ser enumerados: são todos aqueles que sensatamente julgam os agentes morais responsabilizados por suas ações?.

Por fim, os da terceira, bem mais raros e afeitos ao paradoxo que seus concorrentes, são, por conseqüência, os que adotam uma posição particularmente rara. $\mathrm{N}$ este primeiro momento podemos pô- los apenas sob a guarda do estoicismo, sem prejuízo de que, para além do alcance visual de Cícero, a posteridade da história da filosofia fizesse retornar essa alterna tiva reiteradas vezes. Se tal possibilidade conhece renovações e permite novas tentativas ao longo da história da filosofia, podemos, no entanto, conceder facilmente a Cícero que a posição estóica tem particular privilégio de permitir o desenvolvimento que servirá de fundo para todas as tentativas posteriores de conciliação entre destino e liberdade. Daí seu interesse específico. Examinemos o juízo de Cícero a seu respeito.

\section{$\S 4$}

Segundo 0 autor do D e F ato, tudo ocorre como se a posição estóica arbitrasse um acordo entre os extremos da questão, e operasse um remaneja mento de conceitos de uma tal ordem que, a partir disso, fosse realmente 


\section{2}

possível fazer conviver o destino, ou a determinação causal da ação, com a autonomia do agente e, sobretudo, do agente moral. Em resumo: a solução estóica falsifica a alternativa binária entre postular a existência de uma ação livre ou a de um destino ordenador do mundo. Solução astuta porque mantém intactos, justamente, os dois princípios mais caros aos partidos em litígio: de um lado, a natureza e a providência divina permanecem agindo de forma determinada e clara - o mundo está bem arrumado - , de outro, o agente livre permanece carregando o peso de sua ação podemos continuar elogiando e censurando nossos semelhantes, cobertos de razão para isso. A ação humana, pelo menos, pode ser soberana e responsável, ainda que seu lugar de exercício seja justamente um cosmo organizado, e imponha regras rígidas o suficiente para permitir a ordenação de todos seus eventos (inclusive os afazeres humanos). Assim tanto os que tomam o partido da autonomia humana quanto os que tomam o partido da ordem da natureza podem conviver no mesmo mundo.

0 resultado é apreciável, mas Cícero, todavia, parece encarar com desconfiança um tal otimismo estóico - o enredo do D e Fato é, no fundo, o desenvolvimento dessa suspeita. A partir principalmente da argumentação que 0 autor imputa a C risipo, a artimanha estóica termina por anunciar uma recaída ainda mais radical no problema que opunha deterministas e adeptos da ação autônoma. Para o D e fato essa doutrina específica do estoicismo apenas mostra, de forma mais desajeitada, que a tese do destino e da autonomia não podem sobreviver uma ao lado da outra, e tal tentativa de conciliação apenas colabora com todas as seqüelas morais que disto decorre. A razão para isso está, desde o começo, do lado daqueles que defendem uma certa região onde se detecta a autonomia absoluta da ação humana: a ação bruta e determinada pelo destino parece implicar uma certa amoralidade, e é apenas em um mudo de homens autônomos que se pode censurar o facínora ou elogiar o virtuoso. A ssim a pretensão estóica de propor uma alternativa à antinomia destino-responsabilidade vai ser indeferida pelo insucesso em dissolver a contradição fundamental entre estar predestinado e ser responsável.

$\mathrm{N}$ ão que, depois disso, possamos voltar a nos preocupar apenas com a contradição entre os deterministas e os que, por falta de um nome mais preciso, chamaremos de moralistas. Há um partido adotado no De Fato. Cícero se dá ao trabalho de criticar a posição estóica porque toma, franca- 
mente, o partido que concede à ação autônoma o privilégio de permitir 0 desenvolvimento posterior do julgamento moral. A supressão da autonomia de ação, para Cícero, significaria a dissolução das valorações morais na sombra da amoralidade cosmológica subjacente ao conceito de destino universal. 0 mundo moral e responsável já tem a marca indelével da autonomia humana, ou, pelo menos, da ação autônoma - e este mundo é tão distinto da produção homogênea da natureza pura quanto a república dos homens é distinta da paisagem que a circunscreve. A liberdade humana, então, muda a face do mundo e institui, ao lado da sucessão de eventos naturais, a instauração dos eventos deliberados por agentes diferentes, irredutíveis originários e autônomos - por isso mesmo, agentes responsáveis.

0 ponto de Cícero é preciso: se há destino não há autonomia; se não há autonomia são desprovidas de sentido a censura e o louvor, duas conseqüências que destroem a moralidade em seu âmago. 0 primeiro motivo para isso está no desaparecimento da ação singular, objeto privilegiado do louvor e da censura. Com efeito, a natureza, sujeita ao destino universal, é determinada em bloco, ainda que em última instância o seja pela projeção da razão em uma figura divina que a controla. M as aquilo que pode ser elogiado ou censurado, os agentes livres, agem em sua singula ridade, podendo forjar o rumo de suas intervenções ao lado dos outros agentes livres e da natureza - o elogio e a censura não sendo mais que a constatação do acerto ou do erro cometidos na escolha do rumo de uma ação singular. A natureza pode ser ordenada, mas só é digno de elogio ou censura quem é ordenante e, por assim dizer, capaz de impor uma nova direção, uma direção peculiar, ao seu modo de agir.

A ssim, o máximo que Cícero pretende conceder é que ou há o destino como determinação universal, e as ações humanas são sujeitas a essa determinação, tanto quanto operam no mundo real, ou há a liberdade, e a determinação é apenas o comportamento regular da natureza, descontada a presença de entes dotados de autonomia. A evidência desta alternativa, sua mútua excludência, funda-se na contradição entre ter que se determinar por um outro e poder ser determinado exclusivamente por si mesmo. A primeira possibilidade resume o que, segundo Cícero, o partido determinista identifica como destino e a segunda o que seu partido concorrente entendia por autonomia de ação. O s estóicos pretendem fazer conviver as duas cláusulas contraditórias, erro mais perigoso que 0 


\section{4}

do determinista porque, agora, é o próprio conceito de liberdade e de responsabilidade moral que irá ser afetado de alguma obscuridade.

Portanto, se temos de ter cuidado com a argumentação estóica, devemos cuidar ainda mais de sua apresentação ciceroniana - e não porque Cícero parta de um lugar incômodo diante de uma suposta evidência natural da opinião estóica. Pelo contrário. Contra o estoicismo, é fácil conceder, com o D e Fato, que a contradição definitiva entre destino e autonomia parece mesmo ser a única situação aceitável na disputa. Bayle, comentando as mesmas passagens, também cede muito facilmente a essa tentação ${ }^{9}$. N ão obstante isso, nem sempre a argumentação de Cícero consegue desfazer a estranha névoa com a qual o estoicismo cobria 0 conflito entre a aceitação do destino e a postulação da liberdade e da responsabilidade moral. A lgo no paradoxo estóico permanece persuasivo, e é por isso que Cícero decide enfrentá-lo. Para tanto é preciso que o leitor do D e F ato procure entender a maior força do argumento estóico, acima mesmo da desconfiança contínua que Cícero dirige contra ele.

\section{$\S 5$}

U m momento fundamental do D e F ato deixa entrever a melhor estratégia do estoicismo. Ao tratar da maneira segundo a qual Crisipo postula, ao mesmo tempo, a ação soberana do destino e institui a forma mais radical do problema da liberdade, Cícero examina em particular um raciocínio que interessa para a reconstrução argumento estóico, devido à sua força insuspeita. Trata-se de um expediente segundo o qual mantémse a postulação da universalidade da ação causal evitando, no entanto, a necessidade da intervenção do fatum na autonomia de uma natureza livre. A premissa fundamental para isso parte de uma distinção na maneira de encarar a forma pela qual dizemos que um certo conjunto de causas é capaz de determinar seus efeitos. Transcrevemos o testemunho de Cícero por extenso:

"D as causas, diz C risipo, algumas são perfeitas e principais, outras coadjuvantes e próximas. Assim, quando dizemos que tudo ocorre segundo a destinação de causas antecedentes, não desejamos dizer que tudo esteja predeterminado pelas primeiras, mas pelas últimas'. (DF, 18,41). 
Sendo assim, a questão da liberdade se coloca como corolário da maneira segundo a qual pensamos a causalidade nas ações humanas e nos eventos naturais. É bem verdade que até aqui, por certo, não se pressente a novidade da posição estóica. Q ue a questão seja posta nesses termos, isso é, em termos de uma correta compreen são da natureza da causalidade é al go que ainda não surpreenderia nenhum leitor do $D$ e $F$ ato (mas também não surpreenderia um leitor da É tica a N icômaco). C ontudo, se permanecermos no que pode ser inferido da reconstrução de Cícero, não se trataria, por parte de C risipo, de infletir nisso o problema do destino. Com efeito, mesmo que todos os partidos envolvidos na disputa pelo De Fato conviessem em descrever o destino ou a autonomia, antes de qualquer coisa, com uma linguagem eminentemente causal, o ponto do debate estóico ainda guardaria sua novidade a partir dos nuances e da variabilidade que tanto 0 conceito de causalidade quanto a compreensão da ação causal ela mesma podem assumir de escola para escola.

Diante disso, o leitor pode conceder um ponto para os estóicos e escapar um pouco do texto ciceroniano. Há uma desconfiança possível com relação à neutralidade da distinção estóica diante da questão posta por Cícero. C risipo, certamente, não entende a causalidade, por exemplo, em chave aristotélica - a polissemia do conceito de causa é antiga e reconhecidamente um problema: peripatéticos e democriteanos, por exemplo, entenderiam a causalidade com diferenças significativas e enfim, o próprio Cícero poderia estar se servindo de uma noção de causalidade que não predisaria condizer exatamente com a concepção estóica. Tomemos então o cuidado de tentar perceber nos termos literais da argumentação atribuída a C risipo o conceito de causalidade que poderia lhe caber, se é que isso é completamente possível através do testemunho do De F ato.Voltemos agora à passagem de Cícero.

Comecemos pela peculiaridade implicada na classificação das causas. Para interpretarmos de forma correta a posição que Cícero atribui a Crisipo devemos primeiro compreender as oposições estabelecidas pelos adjetivos'perfeitas', 'principais', 'coadjuvantes' e'próximas' quando aplica dos às causas. 0 ra, na formulação ciceroniana, tais adjetivos parecem se organizar aos pares, de maneira que as causas próximas são também coadjuvantes, e as perfeitas, principais. M ais ainda, esses pares de causas são contrapostos uns aos outros de uma maneira precisa, de tal forma que os 


\section{6}

adjetivos empregados para explicar um par exclui o que é usado para explicar o contraposto. A chave para a compreensão do que parece estar em jogo na interpretação ciceroniana de Crisipo está na correta compreensão desse quadro de adjetivos excludentes oferecido pela passagem. 0 jogo de oposições entre os adjetivos pode querer dizer que (1) a causa próxima seja apenas coadjuvante (portanto não implique consigo a possibilidade de explicar totalmente o processo causal em questão) e (2) a causa perfeita seja também principal (o que equivale a ser capaz de, em si mesma, diferir da causa próxima, ao mesmo tempo em que resume a totalidade do processo causal envolvido em um evento).

O ra, as possibilidades (1) e (2) concernem a pontos de vista bastante diversos quando se trata de descrever a etiologia de um evento determinado. A causalidade principal envolve a totalidade dos fatores responsáveis pelo efeito, sem margem para outros fatores causais ou fatores ainda desconhecidos (por isso ela é também perfeita, isto é: completa). A causalidade coadjuvante, por outro lado, permite apenas um elenco de causas próximas que, em si mesmo, não é suficiente para demandar sua completude nem desenhar completamente a fisionomia da totalidade do processo causal se realizando finalmente no efeito. A diferença de pontos de vista pode ser a seguinte: a causalidade perfeita exige do etiologista um olhar de trás para frente, isto é, do todo em ato da ação causal para os fatores parciais que a compõe. Em sentido contrário, a consideração das causas próximas exige um olhar de frente para trás, dos atos dos fatores causais parciais para uma totalidade causal potencial, ainda não composta. A penas nesse último caso a determinação causal é alcançada de tal forma que as causas parciais não explicam toda determinação do ato completo do processo causal de produção.

Entenda-se a o adjetivo "perfeita" na mesma acepção em que um gramático entende os tempos verbais perfeitos - feito até o fim, isto é completo em ato. Daí que, nesse caso, a análise da causalidade exija um exame que parte do evento dado em ato para a postulação de um conjunto completo de causas suficientes e necessárias dado em ato anteriormente, como uma condição que foi cumprida porque 0 evento era efetivo. Em contrapartida a causa que é apenas coadjuvante não precisa ser entendida numa análise que pressuponha 0 evento final acabado e efetivo. $A$ causa é dita coadjuvante, justamente porque é pensada com independência do 
resultado final, no momento mesmo em que atua e enquanto está atuando, de uma forma tal que a "causa coadjuvante" deixa em aberto a necessidade de postular, junto com ela, que seja efetiva a totalidade do conjunto de causas suficientes e necessárias que vão produzir o evento. A diferença entre essas qualificações, assim entendida, pode ser de alguma sutileza, mas as custas de sua importância na reconstrução do argumento de Crisipo. A causa perfeita aparece como tal dado o evento em ato, a causa coadjuvante deve ser pensada como dirigindo-se para um evento que será atualizado. A diferença entre esse dois pontos de vista permite a Crisipo afirmar que se entende a convivência do destino e da autonomia do agente somente da segunda forma, numa atitude de análise que difere daquele que se pergunta pela causa perfeita da forma adequada 10 .

Assim, ao colocar o destino apenas no segundo rol de causas, C risipo faz recuar sua ação para um momento no qual ainda não se decidiu tudo 0 que a causalidade era capaz, e o destino, daqui para frente, será apenas um coadjuvante, ainda permitindo a ação de causas suplementares que, junto com ele, irão compor a causalidade perfeita e principal e, enfim, realizar 0 efeito - todavia o ponto de vista do observador muda consideravelmente depois de realizado o efeito porque, somente então, podemos pressupor a atuação de uma causalidade perfeita. $M$ ais que isso, 0 destino deve ser atuante numa direção determinada: aquela em que examinamos 0 processo causal antes dele se completar e na direção de sua futura composição. Isso que fica em aberto no processo causal assim considera do pode permitir um segundo momento da análise causal. N esse segundo momento apenas, mas de forma decisiva, poderemos ceder espaço à natureza do agente, ou à autonomia de sua ação, como fator que também conta para a consecução total do efeito11.

A aparência de paradoxo que carregava a posição de Crisipo poderia advir apenas de um costume bem estabelecido entre deterministas e adeptos da deliberação autônoma. Ambos tendem a pensar 0 destino como algo que deve aparecer depois da ação completada e a deliberação como algo que deve estar presente antes da ação autônoma. Para um estóico essa formas de considerar os processos causais pode realmente ser uma ilusão de perspectiva que as aparências impõe seja ao determinista seja ao defensor da ação autônoma. 0 ra, C risipo parece querer mostrar que, do ponto de vista das explicações causais das ações deliberadas a 


\section{8}

ordem dos fenômenos deve ser invertida. 0 destino intervém antes da ação completada, pedindo a deliberação do agente autônomo para que se complete a determinação em ato de seus resultados. A deliberação, por sua vez, pressupõe o terreno arado pelo destino, diante do qual ela pode lançar a semente do novo. 0 motivo pelo qual se produz a primeira ilusão deriva da falta de distinção entre duas perspectivas de reconstrução de um processo causal: 1) o que se dirige do todo para as partes, e que trata das causas principais e perfeitas, e 2) o que tenta construir-se das partes para o todo, tomando as causas parciais e coadjuvantes.

Então, podemos inferir que Crisipo, como retratado no De Fato, poderia estar escandindo a análise da causalidade em duas perspectivas diferentes. A primeira determina um evento a partir de um ponto de vista que leva em conta apenas causas parciais, segundo sua contigüidade com o efeito; a segunda perspectiva entende as causas em sua totalidade, agora como completamente determinantes do efeito. Distinção importante porque, se for assim, podemos facilmente entender que as causas parciais (próximas e coadjuvantes) deixam ainda uma certa margem para a ação de outras causas no que concerne à produção do efeito. Por conseqüência, estar predeterminado "pelas causas perfeitas e principais" é diferente de ser condicionado "pelas causas coadjuvantes e próximas" pelo menos no seguinte: as causas próximas e coadjuvantes ainda não fecham todo o horizonte no qual pode desenvolver-se 0 efeito. Se o destino deve ser encontrado apenas nesse plano, não foram fechadas as portas para a autonomia do agente, como uma causalidade paralela e capaz de contribuição para o desenlace do efeito.

Q uando examinamos apenas as causas coadjuvantes sempre restará a possibilidade de termos que levar em consideração a ação insuspeita de causas ainda não identificadas. É o caso, por exemplo, da causalidade que tem sua origem na natureza mesma daquilo que está sujeito às causas coadjuvantes - 0 que, indica de forma clara a maneira pela qual $\mathrm{C}$ risipo pretende conservar a autonomia da vontade diante (ou melhor: ao lado) do destino e da providência. É perfeitamente possível que, para um agente determinado, a causalidade coadjuvante contradiga a tendência de sua natureza (como causa principal de sua ação), mas nesse caso, qualquer que seja o resultado final da ação das causas em jogo - seja ele favorável ou não à deliberação do agente - , não há necessidade de declararmos pre- 
viamente a vitória de uma sobre a outra. Há apenas uma oposição entre a vontade que dirigia a ação e as circunstâncias do agente. A sutileza estóica está toda em fazer-nos considerar a liberdade não a partir do resultado final da ação mas, sobretudo, de trás para frente, pelo modo de agir nela implica do.Tanto faz se a vontade do agente foi cumprida ou não, o que realmente importava era a direção para a qual ela pretendia apontar (o que, longe de ser uma indulgência concedida aos agentes morais, trata-se de uma forma ainda mais dura de julgar sua responsabilidade). A causalidade perfeita produzindo um efeito em ato pode pressupor um fator componente natural e previamente determinado operando em conjunto com uma vontade livre, e de tal forma que o evento final dessa operação não aconteceria assim, sem a ação conjunta dessas partes, e mais que isso, ainda que essas partes, isoladamente, apontassem para direções diferentes. 0 ponto está em que 0 isolamento dessas componentes é apenas uma abstração e na situação concreta apenas sua totalidade dada em ato era importante.

Para percebermos isso no argumento de Crisipo, examinemos uma mesma ação, do ponto de vista de sua causalidade coadjuvante e do ponto de vista de sua causalidade perfeita. N o primeiro caso, reportando-se à totalidade construída das causas em questão, a natureza do agente e seu destino contribuem em proporções determinadas para a consecução de um efeito, ainda quando divergem. 0 ra, o ponto de C risipo parece ser esse: a divergência entre a direção da vontade e as circunstâncias da ação recompõem a causa principal e perfeita tanto quanto sua concordância. C risipo parece dizer simplesmente que a produção de um efeito transborda, por assim dizer, da concordância ou discordância de uma natureza com a concorrência de causas que desenham o destino. Basta ol harmos a sucessão de causas na direção certa e entenderemos afinal que 0 destino expresso no efeito de nossa ação contava também com nossa autonomia, ainda que algum efeito acabado contrariasse suas inclinações. A o fim e ao cabo, a tendência isolada e autônoma da inclinação que se movia livre e autonomamente desde os instantes iniciais da sua ação permanece isolá vel (e julgável) ainda que neutralizada por um golpe do destino - 0 caráter do agente é indiferente às suas circunstâncias; sua virtude não pode ser vista em função de sua fortuna.

De igual maneira, mesmo no momento feliz em que o destino concorda com a vontade, a autonomia desta última permanece, porque a 


\section{0}

vontade, expressão de uma natureza autônoma, já estava resolvida independentemente do resultado da composição das causas principais. Para 0 bem ou para o mal, a vontade, segundo a compreensão do estóico, já está sempre resolvida, mas não determinada por algo que não seja em si mesmo a naturez a autônoma do agente. Esta poderia ser toda a astúcia do argumento de Crisipo.

Portanto, a experiência da liberdade, consoante o espírito do estoicismo de Crisipo, permanece a mesma nos momentos de seu acordo ou desacordo com as causas coadjuvantes que determinam seu exercício (lembremo-nos que, enquanto tais, essas causas são incompletas). Ela tem menos a ver com o resultado final de uma ação e mais a ver com 0 apetite e a tendência da natureza livre. Conclusão em si mesma interessante, pelo menos por indicar um encaminhamento equilibrado para a questão envolvida na relação entre destino, providência, natureza do agente e autonomia da vontade. $N$ esse encaminhamento, o fatum se torna fortuna, e a determinação autônoma da vontade será ou o vício ou a virtude. Estes dois últimos, embora livremente exercidos, não são suficientes para determinar o resultado final da ação, tanto quanto não 0 era a fortuna, uma vez isolada da totalidade dos fatores causais envolvidos em cada evento. A ação viciosa pode falhar (por força do destino) e promover, de malgrado, o resultado digno de uma ação virtuosa, a ação virtuosa, por sua vez, pode produzir um resultado indigno: ainda assim, 0 vício e a virtude do agente permanecem os mesmos, assim como 0 destino que lhe cabia.

\section{$\S 6$}

Todavia, Cícero não julga necessário acatar tão rápido o argumento de Crisipo. U m ponto importante no enredo do $D$ e $F$ ato consiste no recuo que Cícero pretende impor ao seu Crisipo imaginário, justamente depois dessa argumentação. Esse recuo envolverá um novo elemento problemático, agora não mais na estrutura externa da ação (no nexo entre a ação individual e suas circunstâncias), mas em seu enredo interno (isso é, na constituição singular da própria ação livre enquanto tal). Ainda que o problema pareça estar resolvido do ponto de vista da causalidade comple- 
ta e principal, resta ainda questionar a gênese da própria ação autônoma da vontade - que fora tratada até então como um postulado estóico. Cícero procura insistir que essa distinção nas formas de descrever causalmente uma ação contornada por circunstâncias apenas esconde o fato da própria ação livre não poder ser explicada por C risipo. Isso porque se aplicamos a distinção das causas perfeitas e das coadjuvantes na gênese da ação livre ela própria, tal distinção acaba dissolvendo o cerne mesmo da liberdade e da espontaneidade do agente.

Portanto, não parece ser o conflito entre resultado e intenção a preocupação cardinal de Cícero. Sua insistência recai principalmente sobre 0 assentimento (ou ainda, sobre a vontade como causa autônoma, tomada em apartado das demais causas coadjuvantes). 0 argumento ciceroniano insiste em que, ainda que aceitássemos a solução de continuidade entre as causas parciais e a causalidade perfeita, continuaríamos perguntando a Crisipo, e com direito, se o assentimento ele mesmo era determinado ou não, mas agora por causas principais que passavam insuspeitas pelo seu argumento. Em caso positivo o desastre ético da posição estóica seria inevitável e semelhante em tudo ao vazio moral provocado pelo determinismo.

A parentemente, Cícero faz coro, neste momento, com aqueles autores anônimos que negam a necessidade da determinação do assentimento por força de um argumento que, de novo, exibe uma coloração explicitamente moral:

"Se o destino produz tudo, tudo foi produzido por causas antecedentes; e se 0 apetite é produzido assim, também o será o que dele se segue; logo 0 assentimento também. $M$ as se a causa de nosso apetite não está em nós, tal apetite igualmente não estará em nosso poder, como tampouco o que por ele é efetivado. N ão estão em nosso poder, pois, seja 0 assentimento seja a ação. D aí que, com efeito, nem o elogio, nem a censura, nem as honras, nem os castigos são justos". (D e F ato 17, 40).

Em resumo: com que direito C risipo, depois de dizer que tudo está sujeito ao destino, concede ao apetite, ao assentimento ou à vontade individuais de um agente livre, em si mesmas, a condição imaculada de contribuir, por fora disso, como causa autônoma, que também conta para a consecução final da ação? Porque excluí-los do jogo? Q uem disse, então, que o 


\section{2}

próprio assentimento não é também uma circunstância da ação e não venha igualmente determinado pelo destino? E que passe de mágica faria 0 interlocutor de C risipo esquecer-se de que, se concedemos um destino determinando tudo o que acontece, 0 assentimento entre em jogo não ao lado deste destino, mas já sob sua guarda? C ícero, com efeito, julga poder muito bem reconduzir o assentimento da condição de causa determinante à de efeito - e este último tão determinado pelo destino quanto o resultado da ação ele mesmo.

U ma tal objeção recai sobre Crisipo com todo o peso que the emprestava anteriormente 0 resultado indesejável de extinguir 0 valor moral do elogio ou da censura, ou a justiça da retribuição da virtude pela honra e do vício pelo castigo. $M$ as era tal objeção, também, que Cícero fazia Crisipo originalmente tentar responder com a distinção entre as causas totais e as causas parciais da ação (sem que com isso o autor estóico escapasse de ter que se ver, nesse novo nível com o mesmo problema). É verdade que $C$ ícero dava a entender que C risipo pretendia escapar, não sem dificuldades, daquela má conseqüência moral quando emprestava ao assentimento, junto com a vontade, al guma autonomia, mal grado 0 destino. $M$ as é verdade também que Crisipo não parecia estar falando do assentimento simplesmente, mas da concorrência entre um assentimento dado e as circunstâncias de uma ação a ser executada. Daí que, no diálogo sincopado que a impersonação ciceroniana de $C$ risipo trava com Cícero ele mesmo, ao longo do D e F ato, 0 autor estóico continue seu argumento com aquilo que deveria precedê 10 , nos seguintes termos:

"Se tudo é produzido pelo destino, segue-se que as causas anteriores produzem tudo, mas, em verdade, isso não se dá a partir de causas principais e perfeitas, porém, de coadjuvantes e próximas. E se tais coisas não estão em nosso poder, nem por isso 0 apetite deixa de estar. I sso se seguiria apenas ao dizermos que tudo se produz por causas perfeitas e principais, porque, não estando tais causas em nosso poder também o apetite nos escaparia". (D e F ato, 18, 41, grifos nossos).

Com efeito, segundo Crisipo, o assentimento permanece em nosso poder, justamente, porque a determinação do destino não opera no plano das causas perfeitas, o que parece responder à superfície da indagação de Cícero. Isso não obstante, Cícero observa que a resposta de C risipo não 
alcançou suficiência. Para tanto, 0 autor do $D$ e $F$ ato ainda se vê no direito de cobrar do estóico que esclareça em que termos entendia a maneira pela qual 0 assentimento se produzia na natureza autônoma ela mesma.

O ra, o pórtico respondia a isso dizendo que o assentimento manifesta-se na oportunidade de uma imagem que afeta 0 ânimo12. Está aqui a possibilidade de uma réplica de Crisipo. Por isso mesmo essa imagem, para o estóico, é causa coadjuvante e não determina o conteúdo do assentimento ele próprio - ou, utilizando o epíteto com o qual Cícero completa posteriormente a qualificação estóica da causa coadjuvante: a imagem é apenas uma causa extrínseca ( $D$ e F ato, 18, 42) do assentimento. É evidente que, nesse caso, Crispo apenas precisaria repetir o mesmo padrão de seus argumentos anteriores: assim como a vontade do agente e as circunstâncias da ação são causas parciais para a consecução final de um efeito (uma podendo vencer a outra no final das contas) agora uma imagem e a natureza de alguém que foi afetado por ela competem pela responsabilidade final do assentimento. Se a natureza do afetado é preponderante pode haver assentimento autônomo, se a natureza da imagem é hegemônica há apenas passividade do agente, passividade onde deveria haver uma ação. D aí que, ainda em sua passividade, a natureza do agente possa ser julgada. Se a natureza da imagem que dá a oportunidade do assentimento fosse decisiva para determinar 0 afeto final isso se dava, também, por responsabilidade da naturez a do afetado. Pensemos que $\mathrm{C}$ risipo está descrevendo o assentimento como uma competição entre causas parciais. A mais forte determina o resultado final na proporção mesma de sua força, mas ela só pode fazê-lo diante de uma que foi efetivamente mais fraca...

\section{$\S 7$}

A possibilidade do retorno ao padrão argumentativo do estoicismo não é casual. Trata-se ainda de entender corretamente como atuam as causas em questão. D e um lado as causalidades envolvidas competem entre si, mas isso só pode ser postulado se reunimos afinal todas as causas envolvidas e as observamos, também, a partir de sua totalidade. D e outro, as causalidades completam-se sem que nenhuma possa ser dita determinante. $M$ as desse 


\section{4}

último posto de observação a causalidade aparece das partes para o todo, e cada parte do processo causal será tomada extrinsecamente.

O ra, é possível detectar algo mais profundo por trás desse padrão de análise da causalidade. Talvez C risipo pudesse estar postulando uma diferenciação mais radical entre essas duas formas de considerar a causalidade - trata-se agora de conceber diferentemente a causalidade quando é vista como interação entre partes extrínsecas ou como totalidade orgânica. I sto é: os agentes causais podem ser pensados a) seja como entidades separadas, independentes e autônomas umas em relação às outras, e portanto a o conjunto complexo de causas que antecedem o evento é visto apenas como um agregado de partes extrínsecas sem que cada parte possa ser pensada, por si mesma, como algo que contivesse remissão ao todo que deve ser formado para causar algum acontecimento determinado ou b) o conjunto de causas anteriores ao evento pode ser visto como uma totalidade cujas partes pressupõe o todo - a efetivação do evento - , cada causa colaborando e operando como se o fizesse em vista do resultado. 0 segundo tipo de causalidade, sobretudo, pode ser chamado de orgânico, ou pode pressupor uma totalidade orgânica porque exige uma concepção diferente da relação entre o todo formado pela causa perfeita (nome sob o qual se resume todo o conjunto de causas necessárias e suficientes que efetivam 0 evento) e suas partes. 0 primeiro chamamos de causalidade por partes extrínsecas porque cada elemento pertencente ao conjunto das causas não precisa ser pensado em uma relação posśvel com os outros, ou não pressupõe a possibilidade dessa relação. Suspenda-se, por enquanto, a questão de saber se uma tal diferença na concepção da causalidade pode ser caucionada nas coisas elas mesmas' 13 . 0 bserve-se no entanto que, a partir desse uso do termo extrínseca, é a concepção mesma de ação causal que parece ser posta em jogo por C risipo. A partir daí, ainda que Cícero insista na manutenção de seu contra-argumento à posição estóica, como veremos adiante, al go de novo na argumentação de $C$ risipo parecia vir à luz. Essa novidade, ao largo da qual Cícero faz passar 0 argumento do $D$ e $F$ ato, aparece, sobretudo, no momento em que se retoma a explicação de Crisipo a respeito do papel que a natureza de um agente exerce enquanto responsável pelo seu assentimento ou pela capitulação ao destino. A ilustração dessa manobra faz-se por um testemunho notá vel do D e Fato: 
" $<$ C risipo $>$ lança mão, diante disso, de seu exemplo do cilindro e do cone, que não podem começar a mover-se sem impulso <externo>. Isso acontecendo, por suas naturezas, o cilindro irá girar adiante e 0 cone oscilar em ziguezague".

Por conseguinte, diz Crisipo, aquilo que impulsionou o cilindro conferiu- Ihe o início do movimento, mas não seu giro; assim também a imagem (visum objectum) imprime e quase grava sua forma (speciem) no ânimo, mas nosso assentimento permanece ainda em nosso poder e, como dizíamos do cilindro, uma vez impulsionado extrinsecamente será movido, daí para frente, por sua própria força e natureza." (D e F ato, 18, 42-3, grifos nossos) $)^{14}$

Para entendermos corretamente o exemplo de Crisipo, segundo o D e Fato, devemos nos lembrar, com Duhot 15 , que Cícero e os estóicos desconhecem 0 princípio de inércia. Portanto o choque e 0 impulso externos a que se refere o exemplo não implicam uma continuação da ação extrínseca do impulso sobre o cilindro e o cone, sendo apenas ocasiões instantâneas do início do movimento de um e de outro, o mesmo se dando, na analogia, com o ânimo que se vê apenas instantaneamente impulsionado pela imagem (visum objectum, speciem) que o afeta. É 0 decurso da força e da natureza próprias ao ânimo, e apenas eles, que continuam seu movimento na forma do assentimento, para o qual a imagem consiste tão somente em ocasião e oportunidade.

Segundo C risipo, portanto, a causa completa do evento em que damos assentimento a uma imagem, ou que nos inclinamos a alguma coisa, envolve simultaneamente a nós mesmos e ao afeto externo. Assim, também, 0 assentimento se perfaz na totalidade formada pelo ânimo e por todas suas circunstâncias, totalidade que deve ser entendida como causa perfeita e principal da posição finalmente adotada pelo agente. Por outro lado, 0 assentimento como expressão da natureza do ânimo e suas circuns tâncias, quando apartados, são apenas causas próximas e não determinantes: a primeira, por não poder prescindir da necessidade da ocasião extrínseca oferecida por uma imagem que permita o ânimo pôr-se em marcha; a segunda, por não determinar perfeitamente a primeira e ser apenas oportunidade inicial ao lado da qual se soma 0 assentimento. 0 


\section{6}

restante do raciocínio é evidente pelo que vimos C risipo dizer da ação livre ela mesma. A tendência do ânimo, não tendo sido constituída apenas pela imagem (visum), permanece autônoma com relação a ela, e permite, senão ainda a autonomia da vontade e da deliberação, pelo menos a aceitação de que a naturez a do agente, numa medida certa e objetiva, é coresponsável por sua decisão. U m mau ânimo assentiria ao mal e um bom ânimo assentiria ao bem diante das mesmas imagens ou circunstâncias.

Em conseqüência disso C risipo parece querer evitar todas as seqüelas morais da aceitação do destino mesmo quando se trata de aplicá-lo à produção do assentimento - isso é, diríamos numa linguagem contemporânea, quando 0 destino se inflecte sobre fatores psicológicos. 0 s objetos do louvor e da censura continuam sendo acusados consistentemente, a honra e o castigo continuam sendo aplicadas com justiça. Somente é preciso observar que agora, mais que nunca, louvamos ou censuramos uma natureza e uma força intrínsecas ao ânimo do agente. $M$ ais que nunca, porque agora $C$ risipo parece, de novo e com mais razão, poder excluir até mesmo uma consideração última sobre o resultado efetivo da ação questionada, para poder louvá-la ou censurá la. Entenda-se que uma má natureza pode fazer ocorrer uma boa ação, ainda que na tentativa do exercício de algo vicioso (em circunstâncias que, por exemplo, são desfavoráveis à prática do vício ela mesma), ou, vice-versa, uma boa natureza pode desencadear uma má ação quando as circunstâncias conspiram contra seu intento. $M$ as a primeira deliberação continua sendo censurá vel por sua natureza viciosa, e a segunda louvável por seu caráter virtuoso, independentemente dos resultados finais das ações das quais foram, apenas, causas coadjuvantes. 0 conhecimento da natureza do agente é quem decide, no final, 0 acerto do louvor e da censura.

Por certo, seguindo literal mente a imagem de C risipo, o giro do cilindro e o ziguezague do cone devem-se à natureza crua dos dois corpos em movimento, mas ainda que o movimento não se desenvolvesse, sua tendência a se mover assim já estaria presente em ato. 0 sucesso do agente importa menos que as forças mobilizadas em sua ação, e conta muito mais a força bruta constituinte de seu desenvolvimento que o resultado líquido de seu acabamento. A eficácia da ação não está sob o poder do agente, apenas a disposição à ação, e é isso que responsabiliza a natureza do cilindro e do cone mais que a efetividade de seus movimentos característicos. 
C ícero, que possivelmente teria em mente algum contra argumento de C arneades à doutrina do Pórtico, não se contenta ainda com essa resposta. Porque agora, mesmo que possamos responsabilizar a natureza do agente pela direção de sua ação, será justamente tal natureza que irá, num segundo momento determinar sua vontade que, nesse sentido, não parecerá cumprir um dos requisitos fundamentais da deliberação: a escolha entre alternativas possíveis. Por que não dizer que o mau ânimo está destinado ao mal e o bom ânimo ao bem em sua própria naturez a? C risipo, aos olhos de C ícero, desvia do C aríbdis da determinação externa ao Sila da determinação interna. Porém, tanto faz o lugar em que se encontra a determinação. Q uando ela acontece, a possibilidade de deliberar já está bloqueada e a liberdade da vontade definitivamente excluída do processo. Seria então o caso de aceitarmos com Cícero, e tal vez com $C$ arneades, que $\mathrm{C}$ risipo, no que diz respeito à relação entre vontade destino, finalmente terá que se filiar a um dos dois partidos originais (os que simplesmente aceitam ou negam a determinação da vontade) sem poder postular outra posição?

Talvez se faça necessário examinarmos com mais vagar qual poderia realmente ser o ponto finalmente defendido por Crisipo. Para tanto, é preciso, retornarmos mais uma vez ao seu exemplo, sem nos deixarmos enganar pela imagem que ele suscita. $\mathrm{Com}$ efeito, muito do argumento estóico, na forma em que foi apresentado por Cícero, deixa em aberto algumas noções fundamentais ao Pórtico. 0 conceito de natureza do agente, por exemplo. 0 que significaria, a rigor, depositar a responsabilidade pela trajetória dos respectivos movimentos na naturez a do cilindro e do cone - confundindo, como parece sugerir o exemplo de Cícero, tal natureza com sua figura? N ão é o próprio C risipo aquele que, em outra oportunidade, respondia aos democriteanos, relegando à irrealidade a constituição mesma da figura do cone ${ }^{16}$ ?

Com efeito, segundo o testemunho de Plutarco, D emócrito formula va um paradoxo, possivelmente contra-argumentando à idéia de continuidade aplicada à superfície dos corpos físicos, no qual se servia, por uma feliz coincidência, da figura do cone e do cilindro. 0 enunciado do paradoxo pode ser reconstruído a partir do seguinte problema: deter- 


\section{8}

minar se os círculos formados pelo corte de um cone por infinitos planos paralelos a sua base têm um diâmetro menor ou igual ao círculo produzido pelo corte do plano imediatamente anterior.

É fácil perceber que Demócrito certamente pretendia indicar 0 caráter insatisfatório de qualquer resposta a esse problema, principalmente para aqueles interlocutores que pretendiam salvaguardar a idéia da continuidade da superfície de um corpo físico. Seja o primeiro caso aquele em que as circunferências assim produzidas têm diâmetro diferente. Se assim for, perguntar-se-ia com D emócrito, como garantir a continuidade da superfície do cone? Percebendo que essa continuidade exprime-se no fato de imaginarmos a superfície do cone como sendo completamente lisa, a diferença nos diâmetros das circunferências que compõe seu corte horizontal implicaria tantas rugosidades (e descontinuidades) quanto a variação de diâmetro dos infinitos círculos.

Seja o segundo caso, em contrapartida, aquele em que as circunferências possuem diâmetro igual. D emócrito nos responderá que, por conseqüência, o cone não irá diferir de um cilindro.

$0 \mathrm{ra}$, as duas possibilidades parecem muito com uma redução ao absurdo da idéia de continuidade, pelo menos, no que diz respeito à superfície de um cone. 0 argumento de Demócrito, então deveria se assemelhar muito ao seguinte: se não é possível, coerentemente, pensar a continuidade da superfície do cone também não é possível postular a continuidade real da superfície de um corpo na forma de um cone (e, a rigor, de nenhuma outra forma, porque o exemplo do cone apenas traz à luz uma inconsistência que, para Demócrito, deveria caracterizar a continuidade física enquanto tal).

A resposta estóica, munida do espírito próprio à escola, irá recuperar a noção continuidade deslocando completamente a forma pela qual a compreendemos. Então, segundo o mesmo Plutarco, a solução de C risipo ao paradoxo é categórica: as circunferências não são iguais nem desiguais. Bréhier, com razão, sublinha o caráter agudo da resposta: elas não são iguais nem desiguais porque as circunferências, os planos de corte e a própria superfície do cone são incorporais, e portanto não são algo real (isso é: corpos) no sentido preciso que Demócrito esperava que elas fossem ${ }^{17}$.

Assim: 
“É uma resposta da mesma índole das que resultam das demais considerações sobre o contínuo: mostra-se que não há limites na divisão do espaço e que não se pode, por conseguinte, falar de do número de partes contidas em grandezas diversas, como do mundo e do dedo de um homem, porque não há maior e menor no infinito".18

O ra, a superfície é um incorporal, e sendo assim, não possui as propriedades de um corpo, não interage com um corpo nem pode ser pensada como algo no mesmo sentido em que um corpo é algo. Daí segue-se que o movimento do cone e do cilindro, na ilustração que examinávamos anteriormente, no início de nossas considerações, podia muito bem querer dizer algo que nos passou despercebido. 0 movimento do cilindro e do cone não se explica pelo rolamento de suas superfícies como limites externos de um corpo que entram em contato com os limites externos de outros corpos sobre os quais exercem seu movimento, e, por força disso, deslocam-se dessa ou daquela maneira.

Para C risipo, particularmente, tal movimento poderia se explicar, já de imediato, pela naturez a do cone e do cilindro, natureza apenas recoberta pela aparência da oscilação e do giro que operam, respectivamente, quando se movem. Isso é: o caráter externo da explicação de seu movimento surge só no plano das aparências, o movimento real está contido na profundidade do cone e do cilindro - profundidade na qual não há propriamente contato, mas desenvolvimento autônomo e coerente das leis exclusivas de suas naturezas. Explique- se: a figura, cilíndrica ou cônica, é apenas uma aparência que pode ser mais ou menos permanente, assim como a figura de um plano sobre o qual eles se movem. 0 primeiro sintoma disso, no espírito estóico, pode ser encontrado no grau de abstrações que devem ser feitas para a proposição de um modelo no qual se tenha um cone liso, um cilindro absolutamente polido e liso, movendo-se sem atrito e sem interferência sobre um plano perfeito. $\mathrm{N}$ o exemplo estóico não precisa ser isso o importante. São corpos em interação que compões os personagens verdadeiros da imagem proposta por C risipo. O s corpos, por sua vez possuem, uma natureza que se exprime em sua forma e seu comportamento, isso é, sustenta a solidez das aparências. 0 movimento ele mesmo, todavia, acontece na natureza dos corpos e pode por isso mesmo ser expresso também na aparência da trajetória 


\section{0}

reta do cilindro ou tortuosa do cone - mas não se confunda a aparência com o que a sustenta, é a natureza do cone em sua mudança o que se move e, além disso, o lugar no qual o movimento pode ser encontrado.

Passemos isso a limpo. Para C risipo, talvez, a mera ocasião do movimento do cone e do cilindro não esteja somente no instante inicial aquele em que, vimos, os dois corpos recebiam um impulso externo, que não irá continuar pela inércia. Seria perfeitamente coerente com os demais testemunhos da física estóica, pensarmos que o rolamento de uma superfície cilíndrica e outra cônica se movendo por um plano inclinado, por exemplo, fosse também, e apenas, mais uma ocasião na qual se manifesta a natureza dos dois corpos. A saber, se as causas são os corpos e os efeitos incorporais, e aceitamos que tanto o giro da superfície cilindro quanto a oscilação da superfície do cone são efeitos (pelo menos do ponto de vista das aparências), então o fato do cilindro girar e do cone oscilar se exprime inteiramente no ambiente incorporal.

A descrição das causas do giro e da oscilação, no entanto, faz-se em um registro completamente diverso. $\mathrm{N}$ esse último caso, trata-se realmente de naturezas em ação, de corpos em interação. $M$ as essa interação não segue a lógica de um espaço abstrato pensado a partir da relação partes extra partes daquilo que está interagindo. A interação entre os corpora deve ser pensada num campo total no qual todos eles estão interferindo interna mente uns nos outros segundo as leis de suas naturezas singulares. $A$ posição do cilindro no ambiente ao qual pertence não é fortuita, e também não vem de fora. 0 exemplo de $C$ risipo então, descontadas as aparências, quer dizer apenas que a questão a respeito da autonomia do agente, quando posta de fora de sua natureza, é mal posta. Isso é, precisamos tomar a autonomia como ponto de partida, e o erro de Arcesilau, Cícero, e talvez, de Carnéades também, seja simplesmente o de postular, cedo demais, que a autonomia envolva algum problema a ser resolvido pelos artifícios fundados em al guma noção de causalidade pressuposta, quando o que deve acontecer é justamente o contrário. A causalidade é que deve, quando corretamente compreendida, respeitar, enfim, a autonomia dos agentes livres que, para o estóico, estava pressuposta desde 0 início. 0 apelo à causalidade fornece uma forma legítima de explicar, mas não de fundar a autonomia do agente - talvez, para C risipo, a liberdade estivesse posta com a ordem do mundo, daí que não haja, para ele, 
contradição entre a estrutura do cosmo e a liberdade. Lembremo-nos que o princípio que instaura a ordem universal, Zeus entendido como alma do mundo, já era livre desde sempre.

0 exemplo do cone e do cilindro, agora, apenas explicita que a explicação causal deve ser conveniente à expressão da natureza concreta dos agentes concretos, o corpo que se exprime, na aparência, sob a forma do cilindro ou do cone, porque se move como um cilindro ou como um cone, porque fere a vista como um cilindro ou como um cone, porque projeta uma sombra como um cilindro ou como um cone, mas faz tudo a partir de sua natureza mais profunda, que produz por si mesma estes efeitos. A ssim também, a natureza mais profunda dos agentes livres permite a deliberação, como o cone projeta sua sombra, mas isso não os coloca sob o mesmo plano, não transforma as duas coisas em fenômenos fundados a partir de suas causas. Pelo contrário, a causalidade já é apenas expressão de uma natureza em ação, e o fundamento da causalidade está fora da perspectiva causal. A causalidade explica a ação, mas é uma ação originária que funda a possi bilidade dessa causalidade. Somente nesse segundo plano podemos compreender a espontaneidade do agente: ela permite que 0 agente seja uma causa livre e não contrário. A postulação da causalidade livre seria apenas o reconhecimento de que há corpos dotados de espontaneidade em sua natureza. Cícero então seria enredado pela forma segundo a qual se aproximou do problema da relação entre o destino e a liberdade do agente.

Esta relação se explica numa linguagem causal, mas tem seu fundamento na natureza mesma das coisas em sua realidade (ou, para os estóicos, dos corpos). 0 segredo se exprime pela causalidade, todavia, não se resolve por ela. Importa muito pouco, nesse caso, o bom destino seja ou não uma conseqüência causal para aquele que pratica o bem e 0 mau destino para aquele que pratica o mal, 0 agente bom está preso ao bem e o mau agente ao mal em sua própria natureza e, por isso, espontaneamente.

0 que pode estar chocando a sensibilidade moral de Cícero, nesse caso, poderia ser menos a possibilidade do louvor e da censura, mas o fato do destino de uma boa natureza parecer, eventualmente, estar aquém da recompensa, assim como o de uma má natureza situar-se fora do alcance de um devido castigo. $D$ aqui talvez a verdadeira diferença entre $C$ ícero e 0 estoicismo, porque 0 primeiro concede um papel importante à inter- 


\section{2}

venção extrínseca da justiça praticada pelos outros homens na R epública. O s estóicos, resolvem a moral, pelo menos, na imanência da vida do agente moral - poderíamos imaginar $\mathrm{C}$ risipo ou Epicteto se perguntando que problema há diante da ausência de castigo ou de recompensa, uma vez que a paga do vício é o vício e da virtude a virtude.

Voltemos, no entanto, ao argumento. 0 fato está todo em que qualquer ação é cumprimento de uma natureza, e que a segunda, em si mesma, contém e justifica (ou condena) a primeira. De tal forma que, se assim fosse, C risipo não predisava responder à questão que Cícero lhe dirigia imaginariamente.

0 ponto de vista ciceroniano permanece em um lugar completamente diverso. $N$ esse caso, a virtude é o que pode acontecer como resultado de uma ação, e sua ausência é o dado originário. Cícero, então pode reclamar o caráter casual e excepcional da virtude, e basear nisso seu louvor às ações corretamente dirigidas. $M$ as exatamente porque a virtude passa a ter 0 estatuto de mera possibilidade, 0 vício também passa a tê-lo, como alternativa sempre aberta diante da forma de conduzir cada ação. D aí também a oportunidade da censura: ela é proporcional à possibilidade não cumprida do elogio. Para tanto, C ícero precisa tornar a vontade um problema renovável a cada instante em que ela se exerce - um problema sempre novo, porque uma possível má condução da vontade resulta na ameaça constante de ruptura na integridade do caráter do agente moral. $E$, se for assim, não pode haver um destino determinante, sob pena de não compreendermos mais o que seja exatamente a virtude (com efeito, segundo a indicação do D e F ato, C ícero parece concebê-la como sendo a retidão de escolha que se funda apenas na autonomia de uma boa vontade) nem o vício, como efeito de uma vontade desvirtuada.

\section{$\S 9$}

C abem agora alguns esclarecimentos, antes de tentativa de retorno aos temas propriamente leibnizianos. Para tanto, recolham-se conclusões interpretativas que permitem ler 0 argumento de Crisipo, tornando possível antever a simpatia leibniziana. 
Em primeiro lugar, pode parecer que a análise em termos de incorporais deixe sem explicação o que significam todas a metáforas de profundidade que pretendam ser aplicadas à natureza mesma das coisas. É que, de fato, a relação entre os corpos e os incorporais - embora possa ser expressa sob a metáfora do que se revela e o que se esconde, sob o superficial e o profundo, ou ainda por uma série indeterminada de oposições paralelas a essas - parece implicar, antes de mais nada, a oposição entre uma realidade cuja natureza é pura e tão somente ação e uma aparência que estabiliza essa ação às custas de sua realidade. A ssim a natureza íntima do cone e do cilindro seria melhor expressa por um verbo no particípio presente que significasse que algo está sendo à maneira de cilindro, que pelo substantivo. Q ualquer estabilização da ação de ter a história de um cilindro ou de um cone rompe seu compromisso com que sustenta a aparência do cilindro e do cone e nos fornece apenas um fotograma, uma imagem incompleta e imperfeita na medida em que não mostra sua relação com todas as outras imagens que as naturezas do cone do cilindro efetivamente irão sustentar.

Então o primeiro passo consiste em distinguir um plano real, no qual tudo é pura atividade, de um plano aparente, no qual o que se manifesta é apenas sintoma da manifestação de uma natureza. As metáforas profundo-superficial, interno-externo, interior-exterior devem ser corrigidas para que suas implicações espaciais não confundam o ponto em questão: trata-se de decantar, dada uma aparência extática, um suporte de atividade constante e, paralelamente a isso, trata-se também de distinguir o real do aparente a partir da postulação da realidade como causa e atividade como realização em seu sentido legitimamente verbal - , e da aparência como sintoma e imagem isolada de um momento que exprime a natureza. A distância entre 0 real e 0 aparente assim entendidos, mas apenas isso, é o que será retomado pelas metáforas de profundidade, internalidade e assim por diante.

A primeira tese de uma tal interpretação, portanto, será a seguinte:

1) para Crisipo a natureza de uma coisa é a ação constante que se exprime em cada momento de sua existência e funda a coerência dessas expressões.

Em conseqüência disso, observe-se, seria possível justificar o gosto estóico pelas definições genéticas, que declaram a natureza de uma coisa 


\section{4}

pela sua construção, isso é, pela atividade primeira que apresenta todas suas propriedades como conseqüências. Por força disso o cone não é bem definido por fórmulas do tipo:

Cone ${ }_{\text {def. }}$ "figura tridimensional...... com superfície contínua tal que....".

Tal definição, segundo o gosto estóico, poderia ser corrigida pela seguinte:

Cone $=$ def. "o cone é a figura gerada por um triângulo retângulo girando sobre um de seus catetos como eixo".

O bserve-se que se a definição for aceita como genética devemos compreender todas as propriedades geométricas do cone sendo geradas com ele no giro efetivo do triângulo retângulo sobre um de seus lados. Portanto os verbos que exprimem a ação (a de girar, neste exemplo) constituem a espinha dorsal da definição na exata medida em que articulam os elementos estáticos (o triângulo retângulo, um de seus lado toma do como eixo, etc.) na relação que permite deduzir as propriedades do cone (cuja natureza, por assim dizer, é a de um triângulo retângulo girante).

Daí que, em segundo lugar, o plano no qual se exprimem os predica dos de uma coisa, sua figura, a trajetória de seu movimento - mas também suas impressões, decisões e, a rigor, todas as conseqüências de uma natureza qualquer, inclusive a humana - não seja suficiente, quando desligado da consideração da natureza da coisa, para explicar o momento seguinte de sua ação. Cícero, de outro ponto de vista, pode postular a relação entre 0 momento anterior e 0 momento seguinte dessa ação, mesmo no plano das aparências, como causalidade. C risipo reserva a causalidade apenas aos corpos, isso é ao que tem natureza. Portanto, quando C risipo permite uma descrição causal do movimento de um cilindro ou de um cone, ou ainda, chegando ao que importa, do movimento pelo qual se delibera um fim para a ação ele o faz distinguindo o plano da aparição dos sintomas do plano de sua produção. 0 movimento real do cone é o que permite explicar o que há de coerente na sucessão de aparências que exprimem seu movimento numa trajetória determinada. 0 movimento real da deliberação, paralelamente a isso, é o que permite ver a coerência na adoção de um fim determinado, dada a natureza de um agente determinado. $\mathrm{D}$ o que se segue a necessidade de corrigir mais uma vez a definição: 
A ção autônoma = def " evento...... causado unicamente pelo agente",

$\mathrm{N}$ os seguintes termos (que constituem a segunda tese de nossa interpretação):

2) Ação autônoma = def. "expressão da exclusiva natureza do agente, sem a pressuposição de outras naturezas que não estejam presentes em sua definição"

A primeira definição é visivelmente ciceroniana, a segunda pode ser um resultado particular da reconstrução da maneira como $C$ risipo pensa a causalidade nos argumentos que Cícero Ihe atribui. Assim, a ordem estóica para a exposição do problema envolvido na relação entre destino e liberdade - mesmo quando o problema se traduz numa linguagem causal - exige a postulação prévia de uma natureza a partir da qual a causalidade possa permitir a produção dos eventos que a exprimem.

Diante disso C ícero poderia retrucar: mas se há uma natureza dada, como poderia haver escolha? A o que C risipo poderia objetar: como haveria escolha sem uma natureza dada, isto é, sem aquilo que escolhe? Cícero replicaria que uma natureza não está sob o poder de quem a tem, que não há escolha de nossa natureza, sobretudo se ela for dada, e portanto a posição de Crisipo retorna finalmente ao determinismo. Crisipo responderia que, antes de tudo, está sob o poder de uma natureza racional (a natureza humana, que nisso ultrapassa a do cone do cilindro) agir sobre si mesma ainda que de forma limitada. $M$ ais ainda Crisipo poderia responder que uma escolha pressupõe uma natureza dada como uma ação pressupõe um agente. Assim, para C rispo, ao se descrever a deliberação de um agente racional deve-se levar em consideração que: a) uma parte de sua ação pode ter origem em sua natureza apenas, b) que a deliberação efetuada por um agente dotado de uma natureza determinada é coerente com essa natureza, mas, na medida em que é uma expressão dela, c) que a natureza racional implica capacidade de agir sobre si mesma, apenas a partir de si mesma, e então d) uma parte da deliberação de uma natureza racional pode ser devida à sua capacidade de agir sobre si mesma, o que ela faz por si mesma e sem agir com referência outras naturezas que não participem de sua definição, e) a descrição causal dessa deliberação, como um evento, deve ser posterior a isso, e é capaz apenas de organizar a distribuição dos fatores componentes das ações racionais entre aqueles que se devem 


\section{6}

apenas à natureza do agente e aqueles que também pressupõe a ação de naturezas diferentes.

A gora o exemplo do cilindro e do cone, excluído o princípio de inércia como não pertinente à física de $C$ risipo, pode querer dizer o seguinte: assim como o cone e o cilindro se movem de uma maneira determinada a partir de sua própria natureza, um agente racional delibera um fim a partir de sua própria natureza - contudo como um adendo a isso, perceba-se que a natureza racional, diferentemente daquela presente no cone e no cilindro, pode agir sobre si mesma e a partir de si mesma e a trajetória final de seu percurso tem a possibilidade de variar sua direção. C ontudo se levamos em conta todas as causas e todas as naturezas em interação envolvidas em um ação concreta é perfeitamente possível que o fim deliberado pelo agente racional não se realize.

$0 \mathrm{ra}, \mathrm{C}$ risipo poderia perfeitamente censurar o agente racional quando delibera por uma má finalidade ou louvá-lo por escolher uma boa finalidade porque sua naturez a concreta é boa ou má. Independentemente disso a ordem dos demais acontecimentos pode determinar o sucesso ou não da realização do fim deliberado.

Todavia, o que cabe reter é que esse deslocamento contínuo do sentido dos termos necessidade, natureza, evento causalidade, autonomia, e assim por diante tem seu apoio na compreensão da natureza de alguma coisa como a ação real que está pressuposta em cada expressão dessa natureza e é a partir daí que se aplica uma explicação causal da deliberação ou da relação entre a ação livre e 0 destino. Em resumo, $C$ risipo talvez pudesse retrucar ao D e F ato que Cícero estava tentando levar a explicação causal das ações humanas longe demais e que talvez isso mesmo fosse a razão do dilema que opunha deterministas e indeterministas. Tomando a sério a análise da causalidade levada a cabo por $C$ risipo, entendida a noção de autonomia a partir do exemplo do cone e do cilindro, com as devidas correções interpretativas que recobram a física mais provável do Pórtico, pode-se perfeitamente antever alguns dos compromissos inescapáveis ao programa de constituir uma terceira via para além determinismo e indeterminismo. A simpatia de Leibniz pelo exemplo de Crisipo, e pelo fatum stoiaum pode significar que muito desse programa retorna como tarefa daTeodicéia. 
As repetidas observações de Leibniz naTeodicéia (nos parágrafos 169 e seguintes, assim como 331 e seguintes) talvez possam, agora, nos esclarecer um pouco sobre a posteridade de C risipo. Como vimos, não se trata de filiar Leibniz ao partido estóico e Bayle (seu interlocutor mais imedia to) a Cícero. Todavia, se os termos em que se reconstrói o problema da relação entre destino e autonomia do agente, a partir do embate imaginário entre Cícero e Crisipo, acabam desenhando um roteiro estrito dentro do qual o problema pode ser posto, é clara e explicável a simpatia de Leibniz pelo segundo.

C omo isso não se faz por de forma inconteste guardem-se as seguintes ressalvas:

1) Leibniz ele mesmo, anuncia distância entre três concepções do destino: 0 fatum mahumetanum, o fatum stoicum e, por fim o fatum christianum ${ }^{19}$. 0 primeiro seria concebido como puro determinismo, o segundo pode ter as características que destacamos na análise do debate entre Cícero e Crisipo. 0 terceiro, por fim, concerne à verdadeira discussão entre Leibniz e Bayle, e mobiliza necessariamente a aceitação do livre-arbítrio, da existência de um D eus criador e livre e ainda do deslocamento da má ação humana para o campo semântico do pecado.Tudo isso não se aplica ao estoicismo de C risipo.

2) 0 problema, posto à maneira cristã, necessariamente envolve um desenvolvimento extra para que se desculpe a ação divina da criação de naturezas más (o que faria de D eus criador do mal e co-responsá vel pela maldade no mundo criado) ${ }^{20}$.

3) A solução Leibniziana, portanto, deve invocar uma outra física e uma concepção precisa da criação divina, assim como da natureza ontológica do mal, para responder bem a Bayle remetendo-se àquilo mesmo que Crisipo apenas apontava: 0 mal está na natureza do agente21.

Feitas as ressalvas o que resta no paralelo entre Leibniz e C risipo ainda é essencial. $\mathrm{N}$ ão só a responsabilidade pelo mal está na natureza do agente, como também a sua liberdade e autonomia devem ser fundadas em algo de espontâneo nessa natureza. Além disso, tal espontaneidade deve ser entendida no plano dos princípios. A tarefa de Leibniz, ao responder a Bayle talvez seja, então, o cumprimento daquilo que $C$ risipo não podia fazer diante da argumentação de Cícero: cabe a Leibniz fundar 


\title{
168
}

a liberdade, mais que explicá-la, numa linguagem que coerentemente descreva os acontecimentos naturais e humanos sem cindir o mundo numa região da liberdade e outra da determinação natural, reencontrando o meio termo entre os partidos que C ícero punha em disputa no início do D e Fato. $M$ as esse meio termo, agora, se desloca para uma nova região tendo em vista a revelação de um D eus criador.

\author{
${ }^{1}$ C f. LEIBNIZ, 1996b, p. 30 \\ 2 Idem, ibidem. \\ 3 LEIBN IZ, 1996b, pp. 30-31
}

${ }^{4} \mathrm{~A}$ imagem será desenvolvida adiante no $§ 7$.

${ }^{5} \mathrm{~A}$ passagem que Leibniz pretende compara com o símile do cilindro e do cone é a seguinte: "P osons que le courant d'une même riviere emporte avec soy plusieurs bateaux, qui ne different entre eux que dans la charge, les uns étant chargés de bois, les autres de pierre, et les uns plus, les autres moins. $\mathrm{C}$ ela étant, il arrivera que les bateaux les plus chargés iront plus lentement que les autres, pourvu qu'on suppose que le vent, ou la rame, ou quelque autre moyen semblable ne les aide point. $C$ e n' est pas propre ment la pesanteur qui est la cause de ce retardement, puisque les bateaux descendent au lieu de monter, mais c'est la même cause qui augmente aussi la pesanteur dans les corps qui ont plus de densité, c'est à dire qui sont moins spongieux et plus chargés de matiere qui leur est propre; car celle qui passe à travers des pores, ne recevant pas le même mouvement, ne doit pas entrer en ligne de compte. $C$ 'est donc que la matiere est portée originairement à la tardivité, ou à la privation de la vitesse; non pas pour la diminuer par soy même, quand elle a déa reçu cette vitesse, car ce seroit agir, mais pour moderer par sa receptivité l'effed de l'impression, quand elle le doit recevoir. Et par consequent, puisqu'il y a plus de matiere mue par la même force du courant lorsque le bateau est plus chargé, il faut qu'il aille plus lentement. (LEIBN IZ, 1996b, p. 120).

É interessante que Leibniz pretenda fazer a comparação entre essa passagem e o símile de Crisipo ainda que falte a este último um conceito fundamental à primeira: 0 conceito de inércia que permite a Leibniz identificar uma limitação própria à matéria ela mesma. A este respeito $C f$ nota 13 , adiante.

${ }^{6}$ Cf. LAERTIU S, 1995,Vol II,VII, 39-41, pág. 151-152

${ }^{7} \mathrm{~A}$ hipótese de Leibniz é que esta posição de Cícero com relação a A ristóteles se deve a uma leitura canhestra do D e Intepretatione, 9. C f. LEIBN IZ, 1996b, p. 311.

8 Leibniz adianta a possibilidade de localizarmos aí os epicuristas e os acadêmicos (idem, ibidem)

${ }^{9}$ Leibniz ao comentar essa passagem de Bayle concede a facilidade do raciocínio. $\mathrm{N}$ em por isso deixa de posicionara a favor de C risipo. Cf. LEIBN IZ, 1996b § 355 - p. 313).

doispontos, Curitiba, São C arlos, vol. 2, n. 1, p.135-170, outubro, 2005 
10 A qui, como adiante (cf nota 13), não se trata de confundir de imediato o discurso que descreve as causas com uma tentativa de alcançar as coisas elas mesmas. Isso só pode ser feito depois de um ajuste no conceito de causalidade, ajuste sobre o qual o texto de Cícero se cala, embora queiramos vê-lo sugerido pela movimentação mesma do argumento de Crisipo no texto, até sua versão final.

${ }^{11} \mathrm{C} f$ a esse respeito LEIBN IZ, 1996b, § 332 0- p. 312.

12 Traduzindo por 'imagem' o termo original V isum, Cf. D e Fato, pág 42 - apud BR ÉH IER, 1989.

13 É certo que a causalidade, sobretudo em chave estóica, pretende alcançar a constituição íntima das coisas - diríamos, a partir de C hristian Wolf: sua constituição ontológica - mas também é verdade que a passagem do plano que descreve a ação das causas ao que descreve 0 ser mesmo das coisas poderia ser reduzida a uma petição de princípio se disséssemos, simplesmente, que as coisas são assim porque a causalidade opera de uma maneira determinada e, depois disso, que a causalidade revela seus mistérios a partir das coisas elas mesmas.

14 Aulus G ellius dá um testemunho semelhante de C risipo em N oites A ticas, 7, (6), 2, 11 apud. BR ÉHIER, 1989.

15 DUH OT, 1989, pp. 176-7.

16 Cf Plutarco, D e C omm. N ot. Steph. 1079 d 5-10; 1080 b5-10.Ver também a esse respeito o excelente comentário de BR ÉH IER, E. 1989, p. 8.

17 BR ÉHIER , E., 1989, p 8.

18 Idem.

19 Por exemplo, na correspondência com Clarke in: LEIBN IZ, 1996a,VII, p. 391.

20 Como nota Leibniz no $\$ 333$ daTeodicéia (LEIBN IZ, 1996b, p. 312):

"C iceron juge que $C$ hrysippe s' embarrasse d'une telle maniere, que bon gré mal gré il confirme la necessité du destin. M. B ayle est à peu pres du même sentiment (D iđtionn. artic C hrysippe. lit. H .). II dit que @e Philosophe ne se tire point du bourbier, puisque le cylindre est uni ou raboteux, selon que l'ouvrier I'a fait: et qu'ainsi $D$ ieu, la providence, le destin, seront les causes du mal d'une maniere qui le rendra necessaire.»

210 u, como nota ainda Leibniz (idem, §335, p.313):

" $M$ ais revenons au cylindre de $C$ hrysippe. II a raison de dire que le vice vient de la constitution originaire de quelques esprits $\mathrm{O} n$ luy objecte que $\mathrm{D}$ ieu les a formés, et il ne pouvoit repliquer que par l'imperfection de la matiere, qui ne permettoit pas à $\mathrm{D}$ ieu de mieux faire $\mathrm{C}$ ette replique ne vaut rien, car la matiere en elle même est indifferente pour toutes les formes, et $D$ ieu l'a faite L e mal vient plustost des F ormes mêmes, mais abstraites, c'est à dire des idées que $D$ ieu n'a point produites par un ade de sa volonté, non plus que les nombres et les | figures".

doispontos, Curitiba, São Carlos, vol. 2, n. 1, p.135-170, outubro, 2005 


\section{Referências bibliográficas}

BR ÉHIER E. 1989. La théorie des incorporels dans l'ancien stoidsme. Paris: Vrin.

DU H OT, J-J. 1989. L a C onception Stoïcienne de la C ausalité, Paris:V rin.

LEIBN IZ, G. 1996a. D ie philosophischen Schriften. Ed. C. I. Gerhardt. Vol. I-VII. H ildesheim: G eorg O ImsVerlag.

LEIBN IZ, G. 1996b. E ssais deT héodicée sur la bonté de D ieu, la liberté de I'homme et l'origine du mal. In: G . W. L eibniz - D ie philosophischen Schriften. Ed. C. I. Gerhardt.V.VI. H ildesheim: Georg O ImsVerlag.

LAERTIU S, D. 1995. L ives of E minent P hilosophers. London: Loeb classical Library. 